\title{
Pengukuran Performa Produksi Ayam Pedaging pada Closed House System dan Open House System di Kabupaten Malang Jawa Timur Indonesia
}

\section{Production Performance Measurement of Broiler in Closed House System and Open House System in Kabupaten Malang Jawa Timur Indonesia}

\section{S. Pakage1, B. Hartono ${ }^{2}$, Z. Fanani' ${ }^{2}$ B. A. Nugroho' ${ }^{2}$ D. A. Iyai ${ }^{1}$, J. A. Palulungan ${ }^{1}$, A. R. Ollong ${ }^{1}$ dan D. Nurhayati ${ }^{1}$}

${ }^{1}$ Fakultas Peternakan Universitas Papua, Manokwari Papua Barat

${ }^{2}$ Fakultas Peternakan Universitas Brawijaya Malang Jawa Timur.

Corresponding e-mail: stpakages@yahoo.com

\begin{abstract}
This study aims to determine the level of mortality, body weight, feed convertion ratio and performance index levels by farmers using closed house systems and open house systems. The results showed that mortality rates in open house system farmers were better than closed house systems. Body weight of broiler at closed house system is higher than the open house system at an average age of 32 days. The feed convertion ratio on closed house system farms is better than the open house system. Performance index on farmers using closed house systems is higher when compared to open house systems, but both farming system are the best categories.
\end{abstract}

Key words: closed house system, open house system, FCR, performance index, broiler

\begin{abstract}
ABSTRAK
Penelitian ini bertujuan untuk mengetahui indeks performan, tingkat mortalitas, pencapaian bobot badan dan feed convertion ratio yang dicapai oleh peternak yang menggunakan closed house system dan open house system. Hasil penelitian menunjukkan bahwa tingkat mortalitas pada peternak open house system lebih baik dibanding dengan closed house system. Bobot Badan ayam pedaging pada closed house system lebih tinggi dibanding dengan open house system pada umur rata-rata umur panen 32 hari. Feed Convertion Ratio (FCR) pada peternakan closed house system lebih baik bila dibandingkan dengan open house system. Indeks performan pada peternakan dengan closed house system lebih tinggi bila dibanding dengan open house system, namun keduanya termasuk dalam kategori sangat baik.
\end{abstract}

Kata kunci: closed house system, open house system, FCR, indeks performan, ayam pedaging

\section{PENDAHULUAN}

Peternakan merupakan salah satu bagian dari sektor pertanian yang perlu dikembangkan dan dimanfaatkan secara optimal untuk kemakmuran rakyat. Salah satu komoditas peternakan yang potensial dikembangkan adalah ayam pedaging. Hal ini disebabkan karena ayam pedaging menghasilkan daging sebagai sumber protein yang sangat penting bagi manusia. Manfaatnya sebagai sumber protein asal hewani bagi manusia menyebabkan terjadinya peningkatan populasi, produksi dan konsumsi ayam pedaging di Indonesia. Berdasarkan data statistik dari Direktorat Jenderal Peternakan dan Kesehatan Hewan (2017) bahwa, pada tahun 2016 populasi ayam pedaging mencapai 1,6 miliar ekor atau meningkat 6,82 persen bila dibandingkan dengan populasi ayam pedaging pada tahun 2015. Produksi daging ayam pedaging tahun 2016 sebanyak 1,9 juta ton atau mengalami peningkatan sebesar 17,02 persen dari tahun sebelumnya. Peningkatan populasi dan produksi ayam pedaging tersebut didorong oleh: 1) adanya perkembangan yang kuat pada sektor industri hulu peternakan misalnya pabrik pakan, pembibitan dan industri farmasi serta industri hilir yakni rumah potong hewan, restoran dan lain-lain; 2) periode siklus produksi ayam pedaging yang relatf pendek dan perputaran modal relatif cepat sehingga cocok untuk peternakan rakyat; 3) kemampuan dalam menyerap tenaga kerja; dan 4) komoditas ayam berpotensi ekspor.

Usaha peternakan ayam pedaging yang sedang dilakukan di Indonesia terdiri dari open house system dan closed house system. Sistem kandang open house system merupakan sisten kandang terbuka yang dapat menimbulkan respon yang kurang baik ketika kondisi cuaca yang tidak 
mendukung. Pada kondisi temperatur dan kelembaban kandang yang tidak mendukung dapat mengakibatkan menurunnya produksi dan tingkat kematian tinggi. Closed house system merupakan salah satu upaya inovasi teknologi untuk menghadapi perubahan cuaca yang cukup ekstrim, sehingga diharapkan dapat meminimalisasi pengaruh buruk dari kondisi lingkungan atau perubahan iklim di luar kandang. Tujuan penggunaan kandang closed house system adalah menciptakan iklim mikro terkendali di dalam kandang, meningkatkan produktivitas, efisiensi lahan dan tenaga kerja serta menciptakan usaha peternakan yang ramah lingkungan, namun pembangunan closed house system membutuhkan biaya yang sangat mahal.

Tingkat keberhasilan usaha peternakan ayam pedaging pada umumnya ditunjukkan oleh penampilan atau performance produksi. Penampilan atau performance ayam pedaging tersebut dipengaruhi oleh beberapa faktor. Faktor-faktor tersebut antara lain adalah tingkat kematian (mortalitas), bobot badan ayam hidup, feed convertion ratio (FCR) dan umur panen. Tingkat kematian sekitar 5\% untuk peternakan ayam pedaging dianggap berhasil (Kartasudjana dan Suprijatna, 2006). Aspek bobot badan, konsusi ransum, dan konversi ransum ayam pedaging sangat menentukan performans peternakan ayam pedaging. Bobot badan saat potong atau jual menentukan harga jual. Jumlah konsumsi ransum harus seefisien mungkin untuk mencapai bobot badan tertentu. Bobot badan ayam pedaging pada saat panen yaitu $2 \mathrm{~kg}$, untuk mencapai $2 \mathrm{~kg}$ membutuhkan ransum $2.5 \mathrm{~kg} /$ ekor (Kartasudjana dan Suprijatna, 2006). Semakin efisien ransum, maka performans usaha peternakan ayam menjadi lebih baik.

\section{MATERIAL DAN METODE}

Penelitian ini dilaksanakan pada Kecamatan Pangelaran, Dampit and Bantur Kabupaten Malang. Penentuan responden dalam penelitian ini dilakukan secara sengaja dengan pertimbangan bermitra dengan PT. Sinar Sarana Sentosa, Tbk. Jumlah Responden adalah sebanyak 55 peternak ayam pedaging dengan menggunakan closed house system dan 40 peternak open house system. Metode yang digunakan adalah metode deskriptif dengan teknik wawancara yang didasarkan pada kuisioner.

\section{HASIL DAN PEMBAHASAN}

\section{Karakteristik Usaha Peternakan Ayam Ras Pedaging}

Pembahasan mengenai karakteristik usaha peternakan ayam pedaging dengan menggunakan closed house system dan open house system meliputi skala usaha, performan dan deskripsi variabel. Skala usaha pada kedua kelompok peternak meliputi jumlah bibit ayam (DOC), luas kandang dan kepadatan kandang (density), sedangkan faktor-faktor yang mempengaruhi performan ayam pedaging meliputi aspek mortalitas (tingkat kematian), bobot ayam hidup, feed convertion ratio (FCR) dan umur panen. Tingkat keberhasilan usaha peternakan ayam pedaging dapat ditunjukkan oleh nilai indeks performan yang dicapai. Skala usaha, performan dan deskripsi variabel usaha peternakan ayam pedaging pada kedua kelompok diuraikan berikut:

\section{Skala Usaha Ayam Pedaging}

Skala usaha ayam pedaging merupakan jumlah bibit ayam atau day old chick (DOC) yang dipelihara oleh peternak dalam satu kali proses produksi. Banyaknya jumlah bibit ayam (DOC) yang diusahakan peternak ditentukan oleh luasan kandang yang dimilikinya. Rata-rata jumlah bibit ayam pedaging (DOC) yang dipelihara oleh peternak dengan menggunakan closed house system adalah sebesar 11.364 ekor. Jumlah bibit ayam pedaging (DOC) tersebut tersebar dari 8.000-16.000 ekor. Rata-rata jumlah bibit ayam (DOC) tersebut lebih tinggi bila dibandingkan dengan usaha peternak ayam pedaging dengan menggunakan open house system yakni sebesar 6.825 ekor. Jumlah bibit ayam pedaging tersebut tersebar dari 5.000 10.000 ekor. Perbedaan rata-rata jumlah bibit ayam (DOC) tersebut menunjukkan bahwa terdapat juga perbedaan luas kandang antara kedua kelompok peternak ayam pedaging tersebut.

Peternak ayam pedaging dengan menggunakan closed house system memiliki kandang yang luasnya tersebar dari 644-1.600 $\mathrm{m}^{2}$ dengan rata-rata $969 \mathrm{~m}^{2}$. Sedangkan rata-rata luasan kandang yang dimiliki peternak ayam pedaging dengan menggunakan open house system adalah $744 \mathrm{~m}^{2}$ yang tersebar dari 480 sampai dengan $960 \mathrm{~m}^{2}$. Dengan demikian ratarata kepadatan kandang pada kelompok peternak ayam pedaging yang menggunakan closed house system lebih tinggi yakni 12 ekor $/ \mathrm{m}^{2}$ bila 
dibanding pada kelompok peternak ayam pedaging yang menggunakan open house system yang hanya mencapai 9 ekor $/ \mathrm{m}^{2}$. Kepadatan kandang atau kapasitas tampung tersebut menunjukkan ayam pedaging pada kandang closed house lebih baik dari pada open house system karena dapat menampung lebih banyak ayam pedaging dengan luasan kandang yang sama.

Faktor-faktor yang mempengaruhi skala usaha peternakan adalah kemampuan ekonomi peternak, pengalaman peternak, kerjasama usaha dan kepadatan kandang. Peternak yang mampu secara ekonomi akan dapat meningkatkan skala usaha dan juga peternak yang telah berhasil dalam usaha ternaknya akan dapat meningkatkan jumlah DOC secara bertahap serta peternak yang menjalin kerjasama kemitraan akan meningkatkan skala usaha karena terikat dengan kontrak. Penelitian Siswoyo (2002) dilaporkan bahwa rata-rata skala usaha peternakan ayam pedaging dengan pola kemitraan di Kabupaten Malang adalah 6.583 ekor dan peternak mandiri sebesar 1.760 ekor. Penelitian lain oleh Bahari (2010), bahwa rata-rata skala usaha peternakan ayam pedaging dengan pola kontrak di Kabupaten Malang 5.528 ekor, sedangkan pada peternak nonkontrak 2.387 ekor. Skala usaha peternakan ayam pedaging di Kabupaten Malang juga ditunjukkan oleh hasil penelitian Sutawi (2012) menemukan bahwa rata-rata skala usaha ayam pedaging Di Kabupaten Malang adalah sebesar 5.243 ekor. Dalam penelitian ini rata-rata skala usaha ayam pedaging lebih tinggi bila dibandingkan dengan hasil penelitian-penelitian sebelumnya. Hal ini diduga disebabkan karena jumlah sampel yang berbeda dan juga karena dalam penelitian ini yang menjadi perhatian adalah peternak ayam pedaging dengan closed house system dan open house system yang menggunakan faktor-faktor produksi dari sumber yang sama. Kondisi skala usaha, luasan kandang dan kepadatan kandang seperti pada Gambar 1

Gambar 1 menunjukkan bahwa usaha peternakan ayam pedaging dengan menggunakan closed house system dapat meningkatkan daya tampung atau kapasitas kandang. Hal tersebut diduga disebabkan oleh peralatan closed house system yang dapat menciptakan kondisi yang nyaman di dalam kandang dengan mengeluarkan kelebihan panas, kelebihan uap air dan gas-gas yang berbahaya seperti karbon monoksida (CO), karbon dioksida $(\mathrm{CO} 2)$ dan amoniak (NH3) dengan menyediakan kebutuhan oksigen (O2) bagi ayam pedaging.

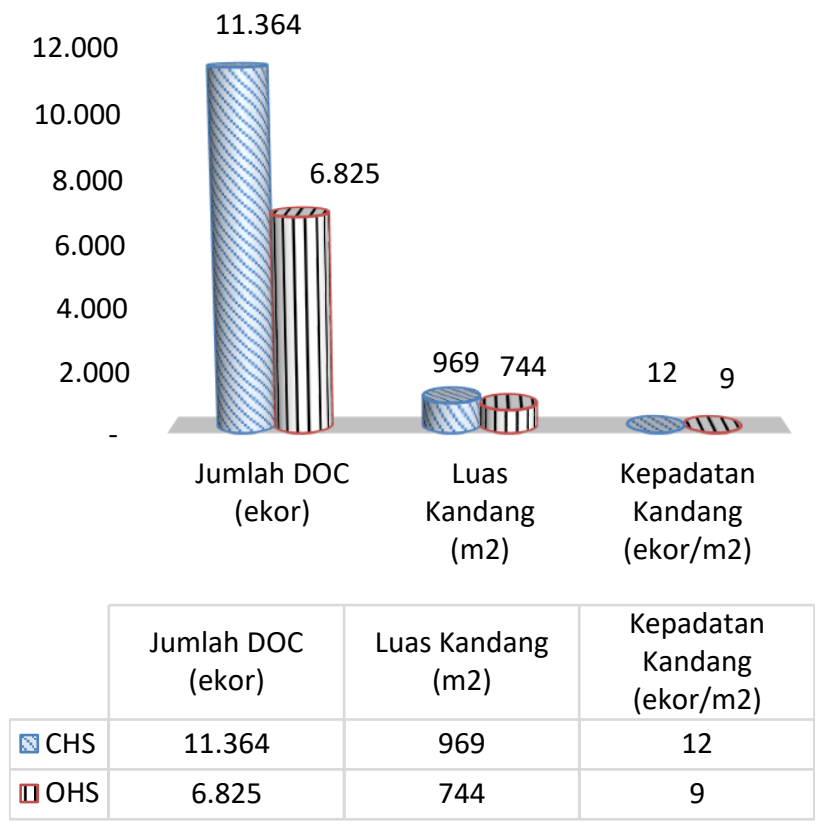

Gambar 1. Skala usaha, luasan kandang dan kepadatan kandang berdasarkan kelompok peternak closed house system dan open house system

\section{Performan Ayam Pedaging}

Tingkat keberhasilan usaha peternakan ayam pedaging pada umumnya ditunjukkan oleh penampilan atau performance produksi. Penampilan atau performance ayam pedaging tersebut dipengaruhi oleh beberapa faktor. Faktor-faktor tersebut antara lain adalah tingkat kematian (mortalitas), bobot badan ayam hidup, feed convertion ratio (FCR) dan umur panen. Faktor-faktor tersebut merupakan indikator untuk dapat mengetahui indeks performance (IP). Faktor-faktor yang mempengaruhi tingkat keberhasilan usaha peternakan ayam pedaging dengan menggunakan closed house system dan open house system disajikan pada tabel 1.

Tabel 1 menunjukkan bahwa rata-rata tingkat kematian atau angka mortalitas pada kelompok peternak ayam pedaging dengan pola closed house system lebih tinggi yakni 7,38 persen (826 ekor) bila dibandingkan peternak ayam pedaging dengan pola open house system yang mencapai 5,24 persen (358 ekor). Hal ini diduga disebabkan oleh faktor manajemen yakni terlambat membuka tirai pada saat terputusnya aliran listrik ke kandang. 
Tabel 1. Keragaan aspek dan indeks performan (IP) berdasarkan kelompok peternak closed house system dan open house system

\begin{tabular}{llcc}
\hline \multirow{2}{*}{ No } & Uraian Aspek Indeks dan IP & \multicolumn{2}{c}{ Rata-rata berdasarkan Kelompok Peternak } \\
\cline { 3 - 4 } & & CHS & OHS \\
\hline 1 & Aspek Indeks: & 7,38 & 5,24 \\
& a. Mortalitas (\%) & 826 & 358 \\
& b. Mortalitas (ekor) & 1,99 & 1,97 \\
& c. Bobot badan ayam hidup (Kg/ekor) & 1,60 & 1,77 \\
& d. Feed Convertion Ratio (FCR) & 32 & 32 \\
& e. Umur panen (Hari) & 336 & 313 \\
\hline
\end{tabular}

Sumber: Olahan data primer

Berdasarkan hasil wawancara bahwa tingkat kematian yang tinggi dialami oleh 2 peternak closed house system yang diakibatkan oleh terputusnya pasokkan listrik akibat tumbangnya pohon, dimana peternak tersebut belum menyiapkan sumber energi listrik cadangan. Pemadaman listrik tersebut mengakibatkan terjadinya peningkatan temperature dan kelembaban di dalam kandang. Peningkatan temperature dan kelembaban tersebut juga dapat berdampak pada ayam pedaging dengan menggunakan pola open house system yang ventilasinya kurang baik.

Temperatur dan kelembaban lingkungan berpengaruh nyata terhadap pertumbuhan. Miharja (1981), menyatakan bahwa temperatur dan kelembaban lingkungan merupakan salah satu faktor penting untuk diperhatikan, karena tingginya temperatur dan kelembaban di daerah tropis merupakan suatu masalah dalam pertumbuhan ayam broiler. Prinsip pertumbuhan dan efisiensi penggunaan ransum yang maksimal tidak akan tercapai apabila ayam broiler dipelihara pada temperatur lingkungan yang tidak sesuai dengan kebutuhannya (Soeharsono, 1976). Kelembaban erat kaitannya dengan temperatur lingkungan dan kadar air yang hilang dari tubuh. Pendapat North (1982) bahwa kelembaban yang ideal untuk unggas di daerah tropis tidak lebih dari $75 \%$, karena bila lebih tinggi maka dapat menyebabkan meningkatnya perkembangan mikroorganisme.

Tingkat mortalitas kedua kelompok peternak ayam pedaging tersebut menunjukkan pada kategori serius karena tingkat mortalitasnya telah melebihi 5 persen. Tingkat kematian yang telah melebihi $5 \%$ tersebut diduga diakibatkan oleh tingginya temperature dan kelembaban akibat terputusnya aliran listrik dan juga disebabkan karena faktor manajemen. Hasil penelitian lain bahwa rata-rata tingkat mortalitas ayam pedaging pada peternak mandiri di Kabupaten Malang pernah berada pada kategori serius yakni mencapai 6,95 persen (Bahari, 2010).

Rata-rata pencapaian bobot badan ayam pedaging hidup pada kelompok peternak closed house system lebih tinggi yakni $1,99 \mathrm{~kg} / \mathrm{ekor}$ dibandingkan pada kelompok peternak open house system yang hanya mencapai $1,97 \mathrm{~kg} / \mathrm{ekor}$. Rata-rata bobot badan yang dicapai tersebut hamper sama antara kedua kelompok peternak tersebut. Pencapaian bobot badan ayam pedaging hidup yang hampir sama antara kedua kelompok peternak tersebut diduga disebabkan oleh penggunaan faktor-faktor produksi (kualitas, ketersediaan dan asal) dan pendampingan yang berasal dari sumber yang sama. Hasil penelitian ini sesuai dengan standar yang ditetapkan Cobb (2006) bahwa pertambahan bobot badan akhir ayam broiler yang dipelihara selama 5 minggu berkisar antara 1.838-2.114 gram dan sama juga dengan pendapat Tobing (2002), bahwa bobot badan akhir ayam broiler adalah pada umur 5 minggu pada kisaran 1.902-2.007 gram. Hal ini juga sama dengan penelitian dari Pakage et al., (2019), Nuryati (2019), Risnajati (2012) dan Uman (2014) yakni pada umur 5 minggu ayam pedaging mencapai 1.900-2,002 gram. Peningkatan bobot badan akhir yang cepat ini disebabkan oleh meningkatnya mutu genetik ayam broiler. Rata-rata waktu yang dibutuhkan ayam pedaging untuk mencapai bobot badan tersebut diatas pada kedua kelompok peternak adalah 32 hari.

Feed conversion ratio (FCR) merupakan banyaknya kilogram pakan yang dikonsumsi 
untuk menghasilkan satu kilogram berat ayam hidup (Fadilah, 2007). Semakin kecil nilai Feed conversion ratio (FCR) semakin baik pengaruhnya terhadap bobot badan ayam pedaging. Rata-rata feed conversion ratio (FCR) pada usaha peternakan ayam pedaging dengan pola closed house system adalah sebesar 1,60 dan pada open house system adalah sebesar 1,77. Rataan konversi ransum hasil penelitian ini sesuai dengan standar yang ditetapkan Cobb (2006) bahwa konversi ransum ayam broiler yang dipelihara selama 5 minggu yang berkisar antara $1,569-1,653$ dan hasil penelitian yang dilakukan oleh Sujana et al. (2011) dalam menguji dan mengevaluasi efektivitas kandang semi closed house system dalam upaya kemampuan produksi ayam broiler bahwa ratarata feed conversion ratio ( $F C R$ ) yang diperoleh sebesar 1,56. Hasil penelitian tersebut lebih baik dari rata-rata feed conversion ratio (FCR) kelompok peternak closed house system. Hal ini diduga disebabkan karena perbedaan jumlah periode produksi dimana dalam penelitian ini sebanyak 5 periode produksi dan yang diteliti oleh Sujana et al. (2011) mengunakan sebanyak 3 periode produksi.

Berdasarkan nilai FCR bahwa rata-rata peternak closed house system membutuhkan 1,60 $\mathrm{kg}$ pakan untuk menghasilkan bobot ayam sebesar $1,99 \mathrm{~kg}$ bobot ayam hidup dan peternak open house system memerlukan 1,77 kg pakan untuk menghasilkan 1,97 $\mathrm{kg}$ bobot ayam pedaging hidup. Dengan demikian perbedaan performan terutama dalam pencapaian bobot badan ayam pedaging hidup dan FCR diduga diakibatkan oleh efek sistem kandang karena adanya kesamaan seluruh faktor produksi yang digunakan dalam proses produksi dan pendampingan antara kedua kelompok peternak. Hal ini disebabkan karena bentuk usaha kemitraan yang terjalin antara kedua kelompok peternak dengan perusahaan inti (Suwarta, 2011; Djunaidi et al., 2016).

Pada akhir pemeliharaan ayam pedaging dari suatu usaha diperlukan untuk menghitung IP (Index Performance). Tujuannya adalah untuk mengetahui sejauh mana tingkat atau skor produktivitas yang mampu dicapai dari hasil budidaya. Hasil penelitian ini menunjukkan bahwa nilai IP (Index Performance) pada peternak closed house system adalah sebesar 336. Nilai tersebut lebih tinggi bila dibandingkan perolehan Indeks Performance (IP) pada peternak open house system yang hanya mencapai 313. Rataan indeks performan pada kedua kelompok peternak termasuk kategori sangat baik. Hal ini sejalan dengan pendapat Aryanti (2010), bahwa nilai indeks performan diatas 301 termasuk kategori sangat baik. Selanjutnya Medion (2010) menyatakan standar IP yang baik adalah diatas 300 , dan semakin tinggi nilai IP maka semakin berhasil peternakan ayam pedaging tersebut. Indeks performan yang dicapai oleh kedua kelompok peternak dalam penelitian ini masih lebih tinggi bila dibandingkan dengan hasil temuan Bahari (2010) yakni kelompok peternak kontrak memperoleh 268,85 dan peternak non kontrak memperoleh 208,57. Demikian juga dengan penelitian dari Marom et al. (2017) dan Nuryati (2019) bahwa indeks performan yang dipeoleh masih lebih tinggi dari 300.

Tingkat mortalitas dan feed convertion ratio $(F C R)$ merupakan aspek-aspek yang sangat penting bagi kedua kelompok peternak karena selain dapat meningkatkan produksi dan juga untuk memperoleh bonus dari pihak inti. Jumlah peternak ayam pedaging dengan pola closed house system dan open house system yang memperoleh bonus mortalitas dan FCR ditampilkan pada Gambar 2 berikut.

Jenis bonus

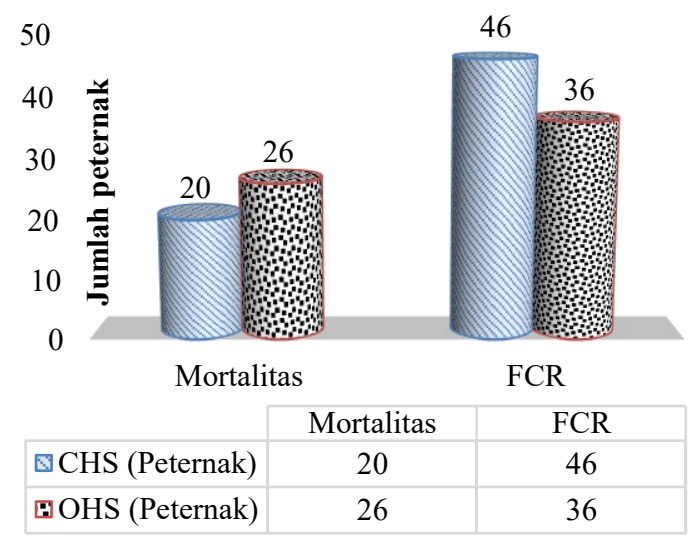

Gambar 2. Banyaknya peternak usaha peternakan ayam pedaging yang mendapat bonus mortalitas dan Feed Convertion Ratio (FCR)

Gambar 2 menunjukkan bahwa 20 peternak ayam pedaging dengan pola closed house system mampu mencapai tingkat kematian (mortalitas) yang lebih rendah dari tingkat mortalitas standart yang ditetapkan oleh pihak inti sedangkan kemampuan peternak ayam pedaging dengan pola open house system dalam 
menurunkan tingkat kematian (mortalitas) lebih baik yakni dalam 26 peternak. Hal tersebut menunjukkan bahwa peternak ayam pedaging dengan pola open house system lebih teliti dalam mengelolah usaha ternak ayam pedaging dengan menerapkan segala informasi yang disampaikan oleh petugas lapang.

Peternak ayam pedaging dengan pola open house system memiliki motivasi yang tinggi untuk memperoleh bonus atas tingkat mortalitas dan FCR bila dibanding peternak ayam pedaging dengan pola closed house system. Pencapaian bonus mortalias dan FCR tersebut menunjukkan bahwa peternak sedang melakukan upaya efisiensi. Motivasi untuk memperoleh bonus mengakibatkan kedua sistem peternakan ayam tersebut telah melakukan usahanya dengan efisiensi baik efisien secara teknis, alokatif dan ekonomi (Pakage et al., 2014; Pakage et al., 2015).

\section{KESIMPULAN}

Tingkat mortalitas pada peternak open house system lebih baik dibanding dengan closed house system. Bobot badan ayam pedaging pada closed house system lebih tinggi dibanding dengan open house system pada umur rata-rata umur panen 32 hari. Feed Convertion Ratio (FCR) pada peternakan closed house system lebih baik daripada open house system. Indeks performan pada peternakan dengan closed house system lebih tinggi bila dibanding dengan open house system, namun keduanya termasuk kategori sangat baik.

\section{DAFTAR PUSTAKA}

Aryanti, F. 2010. Kompetensi kinerja karyawan kandang ayam broiler milik peternak di wilayah desa Cisalopa, Cinagara, Bogor. http://www.deptan.go.id/bpsdm/bbpkh_ci naga ra/index.php?option $=$ com_content\&view $=$ article\&id=69:kinerja-karyawannakkandang\&catid $=28$ :peternakan\&Itemi $\mathrm{d}=44$.

Bahari. 2010. Contract Farming dan Upaya Peningkatan Pendapatan Usaha Ternak Ayam Potong (Broiler). Studi Kasus di Kecamatan Bululawang Kabupaten Malang. Disertasi. Universitas Brawijaya Malang. (Unpublish).
Cobb Breeding Company LTD. 2006. www.cobbvantress. inc.com. (Mei 2014).

Djunaidi, H. I., O. Sjofjan dan S. Anggitasari. 2016. Pengaruh Beberapa Jenis Pakan Komersial terhadap Kinerja Produksi Kuantitatif dan Kualitatif Ayam Pedaging. Buletin Peternakan. 40(3): 187-196.

Fadilah, R. 2007. Ayam Broiler Komersial. Agromedia Pustaka, Jakarta.

Kartasudjana, R. dan E. Suprijatna. 2006. Manajemen Ternak Unggas. Penebar Swadaya. Jakarta.

Marom, A.T., U. Kalsum dan U. Ali. 2017. Evaluasi performani broiler pada sistem kandang close house dan open house dengan altitude berbeda. Dinamika Rekasatwa 2 (2) : 1-10.

Medion, 2010. Berhasil atau Tidakkah Pemeliharaan Broiler Anda. http://info.medion.co.id/index.php/artikel broiler/tata-laksana/berhasil-atau-atautidakkahpemeliharaan-broiler.

Miharja, W. W. 1981. Pengaruh berbagai faktor lingkungan terhadap gala tumbuh ayam broiler. Universitas Padjajaran. Bandung.

Muharlien, M., A. Achmanu, dan A. Kurniawan. 2010. Efek lama waktu pembatasan pemberian pakan terhadap performans ayam pedaging finisher. Ternak Tropika Journal of Tropical Animal Production 11(2): 88-94.

North, M. D. 1982. Commercial Chicken Production Manual. 3rd ed. The AVI Publishing Co., Westport, Connecticut.

Nuryati T. 2019. Analisis Performans Ayam Broiler Pada Kandang Tertutup dan Kandang Terbuka. Jurnal Peternakan Nusantara 5 (2): 77-86.

Pakage, S., B. Hartono, Z. Fanani, and B. A. Nugroho. 2014. Analysis of technical efficiency of poultry broiler business with pattern closed house system in Malang East Java Indonesia. Journal of 
Economics and Sustainable Development 5 (12): 16-22.

Pakage, S., B. Hartono, Z. Fanani, and B. A. Nugroho. 2015. Analysis of technical, allocative and economic efficiency of broiler production using closed house system in Malang District of East Java Indonesia. Livestock Research for Rural Development 27(9): 1-8.

Pakage, S., B. Hartono, Z. Fanani, B. A. Nugroho, dan D. A. Iyai. 2019. Analisis Fungsi Biaya Stochastic Frontier Usaha Peternakan Ayam Pedaging pada Peternak yang Menggunakan Open House System. Jurnal Ilmu Peternakan dan Veteriner Tropis 9 (1): 32-37.

Pakage, S., B. Hartono, B. A. Nugroho, dan D. A. Iyai. 2018. Analisis Struktur Biaya dan Pendapatan Usaha Peternakan Ayam Pedaging dengan Menggunakan Closed House System dan Open House System. Jurnal Peternakan Indonesia 20 (3): 193200.

Risnajati, D. 2012. Perbandingan Bobot Akhir, Bobot Karkas dan Persentase Karkas Berbagai Strain Ayam Pedaging. Sains Peternakan 10 (1): 11-14.

Siswoyo. 2002. Dampak Kemitraan Usaha Ayam Broiler terhadap Daya Tawar dan Pendapatan Peternak di Kabupaten Malang. Tesis S2 (Tidak dipublikasikan).
Soeharsono. 1976. Respon Broiler terhadap Berbagai Kondisi Lingkungan. Disertasi. Universitas Padjadjaran, Bandung.

Sujana, E., S. Darana, dan I. Setiawan. 2011. Implementasi teknologi semi closedhouse system pada perfor-man ayam broiler di test farm sustainable livestock techno park, kampus Fakultas Peternakan Universitas Padjadjaran, Jatinangor. In Seminar Nasional Teknologi Peternakan dan Veteriner (pp. 362-366).

Sutawi. 2012. Analisis sumberdaya domestik kemitraan ayam pedaging dalam usaha pengembangan agribisnis perunggasan. Disertasi. Program Pascasarjana Universitas Brawijaya Malang (tidak dipublikasikan)

Suwarta, Irham, dan Hartono. 2012. efisiensi usaha ternak ayam broiler pola kemitraan inti plasma dan mandiri di Kabupaten Sleman. Berkala Ilmiah Agridevina 1(1): 60-75.

Tobing, V. 2005. Beternak Ayam Broiler Bebas Antibiotika. Penebar Swadaya. Jakarta.

Uman, K. M., S. H. Prayogi, V. M. A. Nurgiartiningsih. 2014. The Performance of Broiler Rearing in System Stage Floor and Double Floor. Jurnal Ilmu-Ilmu Peternakan 24 (3): 79 87. 